\title{
Oxy-steam combustion: the effect of coal rank and steam concentration on combustion characteristics
}

\author{
Ana I. Escudero, María Aznar, Luis I. Díez*
}

\author{
Department of Mechanical Engineering, Joint Institute University of Zaragoza-CIRCE, \\ University of Zaragoza, María de Luna s/n, 50018 Zaragoza, Spain
}

\begin{abstract}
This paper addresses the experimental investigation of coal combustion characteristics (ignition, burnout and NO formation) under oxy-steam combustion conditions. Two coals are selected in order to compare the effect of the rank: bituminous and sub-bituminous ones. The experiments have been conducted in an electricallyheated entrained flow reactor for a set of $\mathrm{O}_{2} / \mathrm{N}_{2}, \mathrm{O}_{2} / \mathrm{CO}_{2}$ and $\mathrm{O}_{2} / \mathrm{H}_{2} \mathrm{O} / \mathrm{CO}_{2}$ atmospheres, with $\mathrm{O}_{2}$ concentrations up to $35 \%$ and $\mathrm{H}_{2} \mathrm{O}$ concentrations up to $40 \%$. Regarding ignition, $10 \% \mathrm{H}_{2} \mathrm{O}$ reduces ignition temperature (max. $16-19 \mathrm{~K}$ ) but the trend is reversed when supplying additional steam to $25 \%$ and $40 \%$. This behaviour is similar for both coals, with slight larger variations in the case of the low rank coal. Burnout degree of the subbituminous coal is barely affected by the steam concentration since all observed conversions are very high. Larger increments (up to 6.1 percentage points) are obtained for the bituminous coal, with a maximum burnout degree for the $25 / 35 \% \mathrm{H}_{2} \mathrm{O} / \mathrm{O}_{2}$ atmosphere. A very different effect of steam on NO formation is found depending on the coal rank. Significant reduction rates are observed for the bituminous coal in comparison to the dry $\mathrm{O}_{2} / \mathrm{CO}_{2}$ atmospheres, with a maximum diminution of $24 \%$ when $40 \% \mathrm{H}_{2} \mathrm{O}$ replaces $\mathrm{CO}_{2}$. On the contrary, the higher volatile content in the sub-bituminous coal leads to NO increments up to $9 \%$. For all the combustion characteristics studied, the increase of $\mathrm{O}_{2}$ concentrations attenuates the effects caused by the steam addition.
\end{abstract}

\section{Keywords}

Oxy-combustion; Steam moderation; Coal rank; Ignition; Burnout; NO formation

\footnotetext{
* Corresponding autor. Tel.: +34 976762 564. E-mail: luisig@unizar.es
} 


\section{Introduction.}

A large deployment of renewable energies is currently being required to obtain a significant reduction of $\mathrm{CO}_{2}$ emissions, as an urgent target to mitigate the effects of global warming. Nevertheless, coal still contributed in 2018 to the $38.5 \%$ of the world electricity production [1]. This global frame turns $\mathrm{CO}_{2}$ capture technologies as essential to match the pathways of the Paris Agreement.

Oxy-fuel combustion is one of the capture technologies suitable for coal-fired power plants. Many results have been obtained in the last years concerning oxy-coal combustion, including lab-, pilot- and demo-scale facilities. A related concept, but significantly new and different, is the so-called oxy-steam combustion. It consists on the full avoidance of the flue gases recycle, replacing $\mathrm{CO}_{2}$ by $\mathrm{H}_{2} \mathrm{O}$ to dilute the oxygen. Condensed water from the flue gases is re-boiled and redirected to the furnace, acting as $\mathrm{O}_{2}$ dilution $[2,3]$. The main advantages of this alternative are simplified plant operation, reduction of auxiliary consumptions and lower air in-leakages. Replacement of $\mathrm{CO}_{2}$ by $\mathrm{H}_{2} \mathrm{O}$ in the firing atmosphere may bring several differences in the combustion characteristics of solid fuels, due to their different thermophysical and chemical behaviour. Some coupled phenomena like volatiles oxidation, char reactivity and conversion, gas-particle heat transfer and pollutants formation/depletion, have to be well characterized to determine the consequences of shifting from the $\mathrm{O}_{2} / \mathrm{CO}_{2}$ atmosphere to the $\mathrm{O}_{2} / \mathrm{H}_{2} \mathrm{O}$ one.

Few studies are available so far addressing oxy-steam combustion of pulverized coal, most of them focused on the ignition behaviour of single/few particles, under different steam concentrations. A summary of experiences, conditions and findings is shown in Table 1. There is not a common outcome from these works, since the effect of steam on ignition depends on several factors like the coal rank, the coal supply conditions (particle size and flow rates), the $\mathrm{O}_{2}$ concentration and the $\mathrm{H}_{2} \mathrm{O}$ concentration [4].

Besides ignition and conversion, steam can also play a role in $\mathrm{NO}_{\mathrm{x}}$ formation/depletion mechanisms. Many studies are available, for a wide range of scales, assessing $\mathrm{NO}_{\mathrm{x}}$ behaviour for $\mathrm{O}_{2} / \mathrm{CO}_{2}$ atmospheres [11-14]. However, the effect of the steam on $\mathrm{NO}_{\mathrm{x}}$ under oxy-combustion conditions has been scarcely investigated, and with limited steam rates. Moron and Rybak [15] investigated $\mathrm{NO}_{\mathrm{x}}$ formation for hard and brown coals in an oxy-fired EFR, with steam addition up to $10 \%$. Steam lowered the $\mathrm{NO}_{\mathrm{x}}$ levels detected. Small influences were reported by Álvarez et al. [16], who conducted oxy-combustion 
experiments for a high-volatile bituminous coal with steam concentrations in the range 5-20\%. Yupeng et al. [17] studied the char-nitrogen conversion for a bituminous coal, under $20 \% \mathrm{H}_{2} \mathrm{O}$ content. They found that steam addition promoted nitrogen release at low oxygen concentration, but it was inhibited at higher oxygen concentrations. To our knowledge, only the work by Zhijun et al. [18] surpassed $20 \% \mathrm{H}_{2} \mathrm{O}$, conducting tests up to $40 \% \mathrm{H}_{2} \mathrm{O}$ for anthracite and bituminous coals in an oxy-fired DTF. These authors reported steam rates minimizing $\mathrm{NO}$ emissions, with a competitive effect between $\mathrm{CO}_{2}$ and $\mathrm{H}_{2} \mathrm{O}$ concentrations in the atmosphere.

\begin{tabular}{|c|c|c|c|c|c|}
\hline Reference & $\begin{array}{l}\text { Coal } \\
\text { type }\end{array}$ & Facility & Atmosphere & $\% \mathrm{H}_{2} \mathrm{O}$ & Main outcomes \\
\hline $\begin{array}{l}\text { Kops et al., } \\
2019[5]\end{array}$ & Sub-bituminous & $\begin{array}{l}\text { DTF + high } \\
\text { speed } \\
\text { camera }\end{array}$ & $\begin{array}{l}\mathrm{O}_{2} / \mathrm{N}_{2} / \mathrm{H}_{2} \mathrm{O} \\
\mathrm{O}_{2} / \mathrm{CO}_{2} / \mathrm{H}_{2} \mathrm{O}\end{array}$ & $0-10 \%$ & $\begin{array}{l}\text { Shortening of ignition } \\
\text { delay time due to steam } \\
\text { addition }\end{array}$ \\
\hline $\begin{array}{l}\text { Riaza et al., } \\
2011[6]\end{array}$ & $\begin{array}{l}\text { Anthracite } \\
\text { Bituminous }\end{array}$ & EFR & $\begin{array}{l}\mathrm{O}_{2} / \mathrm{N}_{2} / \mathrm{H}_{2} \mathrm{O} \\
\mathrm{O}_{2} / \mathrm{CO}_{2} / \mathrm{H}_{2} \mathrm{O}\end{array}$ & 0-20\% & $\begin{array}{l}\text { Increase of ignition } \\
\text { temperature when } \\
\text { replacing } \mathrm{CO}_{2} \text { by } \mathrm{H}_{2} \mathrm{O}\end{array}$ \\
\hline \multirow[t]{2}{*}{$\begin{array}{l}\text { Prationo and } \\
\text { Zhang, } 2016 \\
\text { [4] }\end{array}$} & \multirow[t]{2}{*}{$\begin{array}{l}\text { Bituminous } \\
\text { Sub-bituminous }\end{array}$} & \multirow[t]{2}{*}{$\begin{array}{l}\text { EFR + } \\
\text { high speed } \\
\text { camera }\end{array}$} & \multirow[t]{2}{*}{$\begin{array}{l}\mathrm{O}_{2} / \mathrm{N}_{2} / \mathrm{H}_{2} \mathrm{O} \\
\mathrm{O}_{2} / \mathrm{CO}_{2} / \mathrm{H}_{2} \mathrm{O}\end{array}$} & \multirow[t]{2}{*}{$0-26 \%$} & $\begin{array}{l}\text { The lower the rank of the } \\
\text { coal, the higher the effect } \\
\text { of the steam }\end{array}$ \\
\hline & & & & & $\begin{array}{l}\text { Negligible steam effect for } \\
\mathrm{O}_{2} \text { enriched atmospheres }\end{array}$ \\
\hline \multirow[t]{2}{*}{$\begin{array}{l}\text { Cai et al., } 2016 \\
\text { [7] }\end{array}$} & \multirow[t]{2}{*}{ Bituminous } & \multirow{2}{*}{$\begin{array}{l}\text { DTF + high } \\
\text { speed } \\
\text { camera }\end{array}$} & \multirow[t]{2}{*}{$\mathrm{O}_{2} / \mathrm{CO}_{2} / \mathrm{H}_{2} \mathrm{O}$} & \multirow[t]{2}{*}{$0-30 \%$} & $\begin{array}{l}\text { Negligible effect for steam } \\
\text { up to } 20 \%\end{array}$ \\
\hline & & & & & $\begin{array}{l}\text { Significant ignition } \\
\text { overtake for } 30 \%\end{array}$ \\
\hline $\begin{array}{l}\text { Escudero et al., } \\
2020[8]\end{array}$ & Anthracite & EFR & $\mathrm{O}_{2} / \mathrm{CO}_{2} / \mathrm{H}_{2} \mathrm{O}$ & $0-40 \%$ & $\begin{array}{l}\text { Decrease of ignition } \\
\text { temperature for low steam } \\
\text { rates, increase for the } \\
\text { higher ones }\end{array}$ \\
\hline $\begin{array}{l}\text { Zou et al., } 2015 \\
\text { [9] }\end{array}$ & Bituminous & $\begin{array}{l}\text { DTF + high } \\
\text { speed } \\
\text { camera }\end{array}$ & $\mathrm{O}_{2} / \mathrm{H}_{2} \mathrm{O}$ & $50-79 \%$ & $\begin{array}{l}\text { Shortening of ignition } \\
\text { delay time due to steam } \\
\text { addition }\end{array}$ \\
\hline $\begin{array}{l}\text { Hao et al., } 2019 \\
{[10]}\end{array}$ & Bituminous & $\begin{array}{l}\text { SPR + high } \\
\text { speed } \\
\text { camera }\end{array}$ & $\mathrm{O}_{2} / \mathrm{H}_{2} \mathrm{O}$ & $50-79 \%$ & $\begin{array}{l}\text { Shortening of ignition } \\
\text { delay time due to steam } \\
\text { addition }\end{array}$ \\
\hline
\end{tabular}

Table 1.- Summary of experimental works related to oxy-coal ignition under steam-containing atmospheres. $\mathrm{DTF}=$ drop tube furnace. $\mathrm{EFR}=$ entrained flow reactor. $\mathrm{SPR}=$ single particle reactor.

Our study aims to widen the limited knowledge about coal oxy-combustion with large steam additions as $\mathrm{CO}_{2}$ replacement. In particular, scarce results are reported for low-rank coals. This paper presents a detailed, comprehensive characterization of the oxy-steam combustion characteristics (ignition, burnout and $\mathrm{NO}_{\mathrm{x}}$ formation) for a pair of coals: one sub-bituminous and one bituminous, also seeking the effect of the coal rank on 
81 the results. The experiments are not focused on single/few particles, but on a steady

82 flowrate in an entrained flow reactor, operated under atmospheres containing up to 40\%

$83 \mathrm{H}_{2} \mathrm{O}$ and up to $35 \% \mathrm{O}_{2}$.

93

\begin{tabular}{lll}
\hline Coal & SA & CB \\
ASTM D388-97 & $\begin{array}{l}\text { Medium-volatile } \\
\text { bituminous }\end{array}$ & $\begin{array}{l}\text { B-type } \\
\text { sub-bituminous }\end{array}$ \\
Proximate analysis & & \\
(\% wt.) & & \\
Moisture (as fired) & 3.6 & 7.7 \\
Ash (as fired) & 13.1 & 23.4 \\
Volatile matter (dry ash free) & 30.9 & 46.4 \\
Fixed carbon (dry ash free) & 69.1 & 53.6 \\
& & \\
Ultimate analysis & & \\
(\% wt., dry ash free) & 82.2 & 65.9 \\
Carbon & 4.2 & 3.8 \\
Hydrogen & 2.0 & 0.9 \\
Nitrogen & 0.5 & 10.0 \\
Sulphur & & \\
Heating value & & \\
LHV (kJ/kg, as fired) & 25866 & \\
\hline
\end{tabular}

Table 2.- Coal analysis and heating value.

The moisture, volatile and ash contents of the coal samples were determined according to the standards ISO 5068-2:2007, ISO 562:2010 and ISO 1171:2010,

97 respectively. The elemental analyses were performed using an elemental analyzer 
Thermo Flash 1112. The lower heating values of the samples were determined according to the standard ISO 1928:2009. These results were provided by a certified laboratory, belonging to the Instituto de Carboquímica (Spanish National Research Council).

\subsection{Experimental facility.}

The tests were carried out in a lab-scale entrained flow reactor (EFR), with continuous fuel and gas feeding systems. Figure 1 displays a diagram of the plant. The reactor is made of a Kanthal alloy, with an inner diameter of $38 \mathrm{~mm}$. The height can be varied by a bottom-movable sampling probe, in the range $0.8-1.6 \mathrm{~m}$. The reactor is electrically heated by means of four independent furnaces. Maximum set-point temperature for the furnaces is $1150{ }^{\circ} \mathrm{C}$. The pulverized fuel is supplied by a mechanical screw, driven by a variable-frequency motor. Several mass flow controllers provide the gases from bottles, while a Coriolis flow meter is used to control water flowrate.

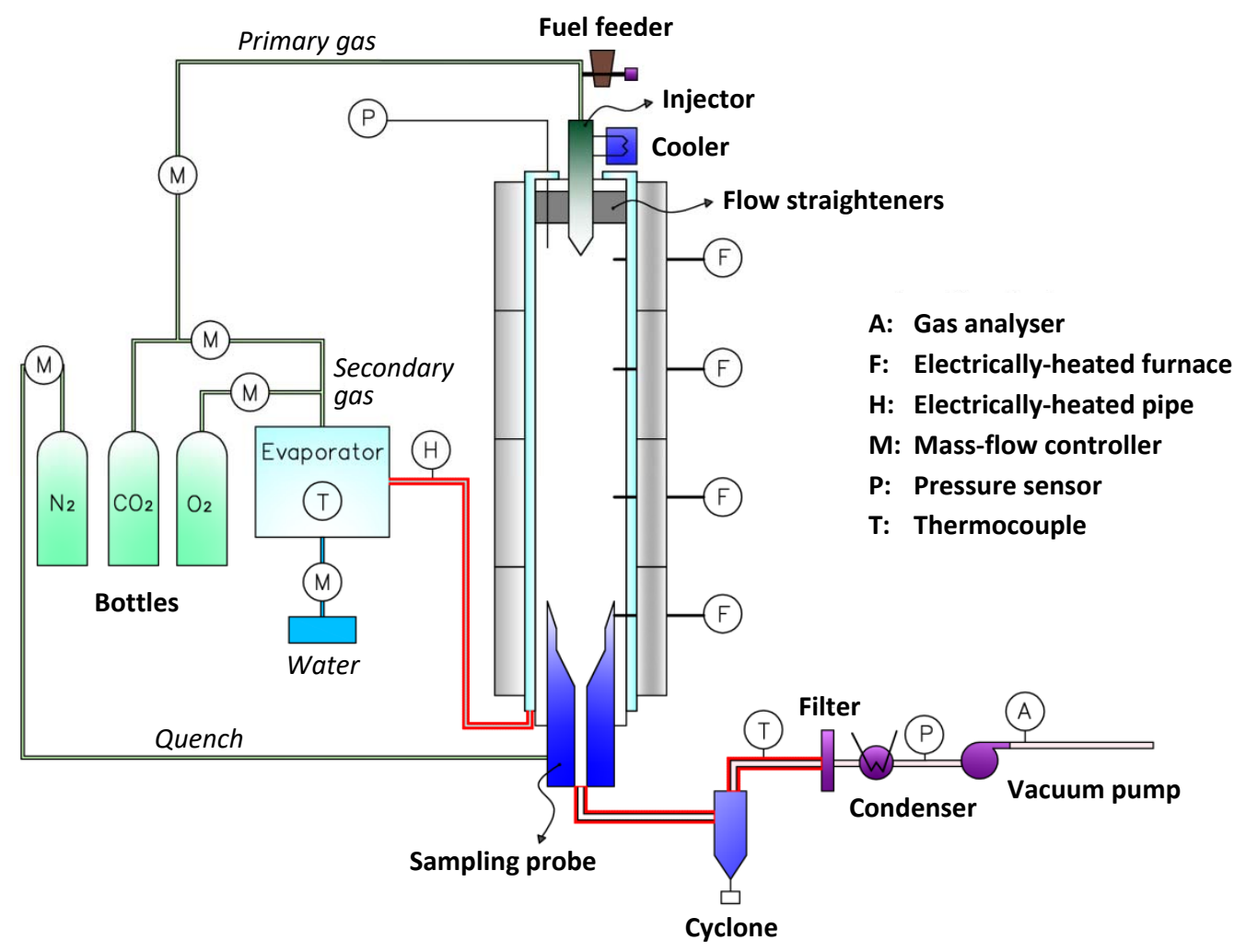
stream, and then a condenser is placed to remove most of the moisture in the flue gases. 
114 Finally, a continuous emission monitoring system provides the flue gas composition at

115 the cold-end section: non-dispersive infrared sensors for $\mathrm{CO}_{2}, \mathrm{CO} \mathrm{SO}_{2}, \mathrm{NO}$, and 116 paramagnetic sensor for $\mathrm{O}_{2}$. A more detailed description of the facility can be found 117 elsewhere [8]. Table 3 summarizes the accuracy of the instruments used for 118 measurements during the tests.

119

\begin{tabular}{ll}
\hline Measurement & Accuracy \\
\hline Feeding gases flow rate $\left(\mathrm{O}_{2}, \mathrm{CO}_{2}, \mathrm{~N}_{2}\right)$ & $\pm 0.5 \%$ \\
Feeding water flow rate & $\pm 0.2 \%$ \\
Temperature & $\pm 2^{\circ} \mathrm{C}$ \\
Pressure & $\pm 3 \mathrm{mbar}$ \\
Flue gases composition $\left(\mathrm{CO}_{2}, \mathrm{SO}_{2}, \mathrm{CO}, \mathrm{NO}\right)$ & $\pm 1 \%$ \\
Flue gases composition $\left(\mathrm{O}_{2}\right)$ & $\pm 1.5 \%$ \\
\hline
\end{tabular}

120

121

122

123

124

Table 3.- Accuracy of the on-line measurements.

\subsection{Experimental procedure.}

\subsubsection{Ignition tests.}

The effect of oxygen concentration $\left(21\right.$ and $\left.35 \% \mathrm{O}_{2}\right)$ and steam addition $(0,10,25$ and 40\%) over the ignition temperature has been experimentally assessed for the two selected coals (SA bituminous and CB sub-bituminous). Thus, sixteen oxy-fired trials were conducted in the entrained flow reactor (eight for each coal). Besides, two additional tests were run under conventional combustion $\left(21 / 79 \% \mathrm{O}_{2} / \mathrm{N}_{2}\right)$. The reactor was heated from room temperature to $1000{ }^{\circ} \mathrm{C}$, at a fixed heating rate of $15{ }^{\circ} \mathrm{C} / \mathrm{min}$. $\mathrm{O}_{2}$ and $\mathrm{CO}_{2}$ concentrations in flue gases were recorded to determine the ignition point. In this way, three zones are identified: 1) pre-ignition, where changes in $\mathrm{CO}_{2}$ and $\mathrm{O}_{2}$ concentrations can be neglected, 2) ignition and conversion of particles, where $\mathrm{CO}_{2}$ concentration begins to quickly grow at the same time that $\mathrm{O}_{2}$ concentration decreases, and 3) steady-evolution when burnout is reached, and concentrations remain constant. This indirect method has been previously used by other researchers [19, 20]. In our case, ignition temperature $T_{\text {ig }}$ is obtained from the following approach:

$$
\left|\frac{\left[X\left(T_{i g}\right)\right]-\left[X\left(T_{p}\right)\right]}{\left[X\left(T_{b o}\right)\right]-\left[X\left(T_{p}\right)\right]}\right|=0.1
$$


138 where $\left[X\left(T_{\mathrm{p}}\right)\right]$ is the $\mathrm{O}_{2}$ or $\mathrm{CO}_{2}$ molar concentration during the pre-ignition temperatures 139 range, $\left[X\left(T_{\mathrm{bo}}\right)\right]$ is the molar concentration when steady burnout degree is reached and $140\left[X\left(T_{\mathrm{ig}}\right)\right]$ is the molar concentration at the ignition temperature point. The ignition 141 temperature was obtained by averaging the results obtained from $\mathrm{O}_{2}$ and $\mathrm{CO}_{2}$ 142 measurements.

\subsubsection{Oxy-steam combustion tests.}

144 Combustion experiments were carried out under different atmospheres: $21 / 79 \% \mathrm{O}_{2} / \mathrm{N}_{2}$, $145 \quad 21 / 79 \% \quad \mathrm{O}_{2} / \mathrm{CO}_{2}, 30 / 70 \% \quad \mathrm{O}_{2} / \mathrm{CO}_{2}$ and $35 / 65 \% \mathrm{O}_{2} / \mathrm{CO}_{2}$. To assess the effect of steam 146 moderation, it was added to the oxy-firing atmospheres replacing $\mathrm{CO}_{2}$ at the following 147 percentages: $10 \%, 25 \%$ and $40 \%$ for a fixed value of oxygen excess $(\lambda=1.25)$. Thus,

14813 tests were carried out for each coal. In order to compare the results obtained under 149 the different situations (coal type, \% $\mathrm{O}_{2}, \% \mathrm{H}_{2} \mathrm{O}$ ), the experimental conditions were 150 defined to keep the same mean residence time (3 s) for all the tests. The corresponding 151 flow rates are presented in Tables 4 and 5. The initial reactor temperature was kept at $1521000{ }^{\circ} \mathrm{C}$ throughout the experimental campaign, while the reaction height was set to $1531.5 \mathrm{~m}$. The independent effect of oxygen excess $(\lambda=1.35, \lambda=1.45)$ was also analysed by 154 means of some additional tests for the dry atmospheres.

\begin{tabular}{llcccc}
\hline $\begin{array}{l}\text { Test } \\
\#\end{array}$ & $\begin{array}{l}\text { Atmosphere } \\
\text { (\% vol.) }\end{array}$ & $\begin{array}{c}\text { Coal } \\
\text { flow rate } \\
(\mathrm{g} / \mathrm{min})\end{array}$ & $\begin{array}{c}\mathbf{O}_{2} \\
\text { flow rate } \\
(\mathrm{g} / \mathrm{min})\end{array}$ & $\begin{array}{c}\mathbf{C O}_{2} \\
\text { flow rate } \\
(\mathrm{g} / \mathrm{min})\end{array}$ & $\begin{array}{c}\text { Water } \\
\text { flow rate } \\
(\mathrm{g} / \mathrm{min})\end{array}$ \\
\hline $\mathbf{1}$ & $21 / 79 \mathrm{O}_{2} / \mathrm{N}_{2}$ & 0.55 & 1.39 & $4.59\left(\mathrm{~N}_{2}\right)$ & 0 \\
\hline $\mathbf{2}$ & $21 / 79 \mathrm{O}_{2} / \mathrm{CO}_{2}$ & 0.55 & 1.39 & 7.21 & 0 \\
$\mathbf{3}$ & $21 / 69 / 10 \mathrm{O}_{2} / \mathrm{CO}_{2} \mathrm{H}_{2} \mathrm{O}$ & 0.55 & 1.39 & 6.30 & 0.37 \\
$\mathbf{4}$ & $21 / 54 / 25 \mathrm{O}_{2} / \mathrm{CO}_{2} \mathrm{H}_{2} \mathrm{O}$ & 0.55 & 1.39 & 4.93 & 0.93 \\
$\mathbf{5}$ & $21 / 39 / 40 \mathrm{O}_{2} / \mathrm{CO}_{2} / \mathrm{H}_{2} \mathrm{O}$ & 0.55 & 1.39 & 3.56 & 1.49 \\
\hline $\mathbf{6}$ & $30 / 70 \mathrm{O}_{2} / \mathrm{CO}_{2}$ & 0.78 & 1.96 & 6.29 & 0 \\
$\mathbf{7}$ & $30 / 60 / 10 \mathrm{O}_{2} / \mathrm{CO}_{2} / \mathrm{H}_{2} \mathrm{O}$ & 0.78 & 1.96 & 5.39 & 0.37 \\
$\mathbf{8}$ & $30 / 45 / 25 \mathrm{O}_{2} / \mathrm{CO}_{2} / \mathrm{H}_{2} \mathrm{O}$ & 0.78 & 1.96 & 4.05 & 0.92 \\
$\mathbf{9}$ & $30 / 30 / 40 \mathrm{O}_{2} / \mathrm{CO}_{2} / \mathrm{H}_{2} \mathrm{O}$ & 0.78 & 1.96 & 2.70 & 1.47 \\
\hline $\mathbf{1 0}$ & $35 / 65 \mathrm{O}_{2} / \mathrm{CO}_{2}$ & 0.90 & 2.27 & 5.79 & 0 \\
$\mathbf{1 1}$ & $35 / 55 / 10 \mathrm{O}_{2} / \mathrm{CO}_{2} / \mathrm{H}_{2} \mathrm{O}$ & 0.90 & 2.27 & 4.90 & 0.36 \\
$\mathbf{1 2}$ & $35 / 40 / 25 \mathrm{O}_{2} / \mathrm{CO}_{2} / \mathrm{H}_{2} \mathrm{O}$ & 0.90 & 2.27 & 3.57 & 0.91 \\
$\mathbf{1 3}$ & $35 / 25 / 40 \mathrm{O}_{2} / \mathrm{CO}_{2} / \mathrm{H}_{2} \mathrm{O}$ & 0.90 & 2.27 & 2.23 & 1.46 \\
\hline
\end{tabular}




\begin{tabular}{llcccc}
\hline $\begin{array}{l}\text { Test } \\
\text { \# }\end{array}$ & (\% vol.) & $\begin{array}{c}\text { Coal } \\
\text { flow rate } \\
(\mathrm{g} / \mathrm{min})\end{array}$ & $\begin{array}{c}\mathbf{O}_{2} \\
\text { flow rate } \\
(\mathrm{g} / \mathrm{min})\end{array}$ & $\begin{array}{c}\text { CO } \\
\text { flow rate } \\
(\mathrm{g} / \mathrm{min})\end{array}$ & $\begin{array}{c}\text { Water } \\
\text { flow rate } \\
\text { (g/min) }\end{array}$ \\
\hline $\mathbf{1}$ & $21 / 79 \mathrm{O}_{2} / \mathrm{N}_{2}$ & 0.81 & 1.36 & $4.49\left(\mathrm{~N}_{2}\right)$ & 0 \\
\hline $\mathbf{2}$ & $21 / 79 \mathrm{O}_{2} / \mathrm{CO}_{2}$ & 0.81 & 1.36 & 7.06 & 0 \\
$\mathbf{3}$ & $21 / 69 / 10 \mathrm{O}_{2} / \mathrm{CO}_{2} \mathrm{H}_{2} \mathrm{O}$ & 0.81 & 1.36 & 6.17 & 0.37 \\
$\mathbf{4}$ & $21 / 54 / 25 \mathrm{O}_{2} / \mathrm{CO}_{2} \mathrm{H}_{2} \mathrm{O}$ & 0.81 & 1.36 & 4.83 & 0.91 \\
$\mathbf{5}$ & $21 / 39 / 40 \mathrm{O}_{2} / \mathrm{CO}_{2} / \mathrm{H}_{2} \mathrm{O}$ & 0.81 & 1.36 & 3.49 & 1.46 \\
\hline $\mathbf{6}$ & $30 / 70 \mathrm{O}_{2} / \mathrm{CO}_{2}$ & 1.12 & 1.90 & 6.11 & 0 \\
$\mathbf{7}$ & $30 / 60 / 10 \mathrm{O}_{2} / \mathrm{CO}_{2} / \mathrm{H}_{2} \mathrm{O}$ & 1.12 & 1.90 & 5.24 & 0.36 \\
$\mathbf{8}$ & $30 / 45 / 25 \mathrm{O}_{2} / \mathrm{CO}_{2} / \mathrm{H}_{2} \mathrm{O}$ & 1.12 & 1.90 & 3.92 & 0.89 \\
$\mathbf{9}$ & $30 / 30 / 40 \mathrm{O}_{2} / \mathrm{CO}_{2} / \mathrm{H}_{2} \mathrm{O}$ & 1.12 & 1.90 & 2.62 & 1.43 \\
\hline $\mathbf{1 0}$ & $35 / 65 \mathrm{O}_{2} / \mathrm{CO}_{2}$ & 1.30 & 2.19 & 5.60 & 0 \\
$\mathbf{1 1}$ & $35 / 55 / 10 \mathrm{O}_{2} / \mathrm{CO}_{2} / \mathrm{H}_{2} \mathrm{O}$ & 1.30 & 2.19 & 4.74 & 0.35 \\
$\mathbf{1 2}$ & $35 / 40 / 25 \mathrm{O}_{2} / \mathrm{CO}_{2} / \mathrm{H}_{2} \mathrm{O}$ & 1.30 & 2.19 & 3.45 & 0.88 \\
$\mathbf{1 3}$ & $35 / 25 / 40 \mathrm{O}_{2} / \mathrm{CO}_{2} / \mathrm{H}_{2} \mathrm{O}$ & 1.30 & 2.19 & 2.15 & 1.41 \\
\hline
\end{tabular}

All the results related to the combustion tests - sections 3.2, 3.3, 3.4- have been obtained from measurements taken under steady-state operation (mass flow rates, temperatures, pressures and flue gases composition). Once the furnace temperature set-

162 point is achieved, coal feeding starts. After a short transient period, composition of flue 163 gases is stabilized and then operation reaches the steadiness. Data are recorded every 5 seconds, and steady periods can last up to 60 minutes. Flame temperature inside the reactor is higher than the furnace set-points, and only one electrical furnace (the bottommost one) is supplying its full power during the combustion tests.

Solid residues in cyclone were also collected during the steady-state regime. Ash 168 weight fractions in these solid residues were determined according to the standard UNE169 32-004-84. Coal burnout degree $\beta$ was calculated by the ash tracer method:

$$
\beta=\frac{\alpha_{f}-\alpha_{i}}{\alpha_{f}\left(1-\alpha_{i}\right)}
$$
where $\alpha_{\mathrm{f}}$ is the ash weight fraction (dry basis) of solid residues recovered in the cyclone and $\alpha_{\mathrm{i}}$ is the ash weight fraction (dry basis) of the fired coal.

The closures of elemental carbon balances and heat balances have been done for the combustion tests. The deviations of the mass balances range $\pm 4 \%$, while the deviations of 175 the heat balances are comprised within $\pm 6 \%$. The heat balances can be only closed for the 176 tests with the higher steam concentrations (25\% and $40 \%$ vol.), since then the bottom 
probe is not water-cooled -this prevents the condensing in flue gases prior to the cyclone and filter, and a possible blockage-. Anyway, the low deviations in the available mass and heat balances support the reliability of the results obtained.

\section{Results and discussion.}

\subsection{Ignition.}

Figure 2 displays the results for the ignition temperatures of both coals, under air $\left(21 / 79 \% \mathrm{O}_{2} / \mathrm{N}_{2}\right)$ and several $\mathrm{O}_{2} / \mathrm{CO}_{2}$ and $\mathrm{O}_{2} / \mathrm{H}_{2} \mathrm{O} / \mathrm{CO}_{2}$ conditions. The larger amount of volatile matter in the $\mathrm{CB}$ sub-bituminous coal leads to lower values of the ignition temperatures in comparison to the SA bituminous one. But the effect of changing the atmosphere is quite similar for both coals.

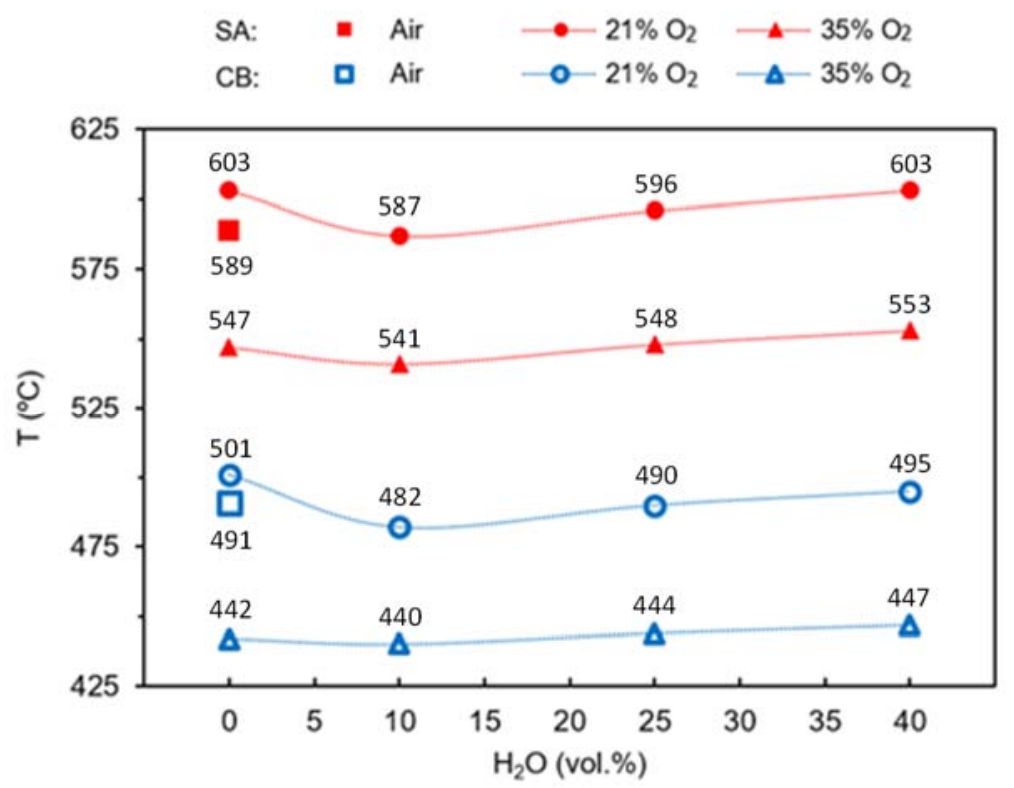

Figure 2.- Ignition temperatures under air and different $\mathrm{O}_{2} / \mathrm{CO}_{2}$ and $\mathrm{O}_{2} / \mathrm{H}_{2} \mathrm{O} / \mathrm{CO}_{2}$ atmospheres (steam is added as $\mathrm{CO}_{2}$ replacement). SA: bituminous coal. $\mathrm{CB}$ : sub-bituminous coal.

When $79 \% \mathrm{~N}_{2}$ is substituted by $79 \% \mathrm{CO}_{2}$, an increase is observed in the ignition temperatures ( $14 \mathrm{~K}$ for the bituminous and $10 \mathrm{~K}$ for the sub-bituminous). Due to the higher specific heat of $\mathrm{CO}_{2}$ in comparison with $\mathrm{N}_{2}$, the temperature increase of the $\mathrm{CO}_{2}$-containing atmosphere around the particle is comparatively lower during the heat 
lower than in $\mathrm{N}_{2}$. If the $\mathrm{O}_{2}$ concentration is risen, from $21 / 79 \% \mathrm{O}_{2} / \mathrm{CO}_{2}$ to $35 / 65 \% \mathrm{O}_{2} / \mathrm{CO}_{2}$, the ignition temperature decreases ( $56 \mathrm{~K}$ for $\mathrm{SA}$ and $59 \mathrm{~K}$ for $\mathrm{CB}$ ) due to the higher oxidation rates caused the by the oxygen partial pressure $[4,6]$.

When $10 \% \mathrm{H}_{2} \mathrm{O}$ is added as $\mathrm{CO}_{2}$ replacement in the $21 \% \mathrm{O}_{2}$ cases, there is an advancement of the ignition: a decrease of $16 \mathrm{~K}$ for the SA bituminous coal and $19 \mathrm{~K}$ for the CB sub-bituminous one. Several phenomena explain this reduction of the ignition temperature: 1) the lower value of the molar specific heat of $\mathrm{H}_{2} \mathrm{O}$ in comparison with $\mathrm{CO}_{2}, 2$ ) the higher $\mathrm{O}_{2}$ diffusivity in $\mathrm{H}_{2} \mathrm{O}$ in comparison to $\mathrm{CO}_{2}$, and 3) the increase of $\mathrm{H}_{2}$ concentration due both to the char gasification by steam and to the water-shift reaction in the gas-phase $[5,9,10]$. This influence of the $10 \% \mathrm{H}_{2} \mathrm{O}$ addition can be also observed for the $35 \% \mathrm{O}_{2}$ atmospheres, but with a more limited extent.

However, if the steam concentration is increased from $10 \%$ to $25 \%$ the trend is reversed and the ignition temperature increases. This behaviour is related, on the one hand, to the increase of radiative absorption by $\mathrm{H}_{2} \mathrm{O}$ in comparison to $\mathrm{CO}_{2}$. According to Cai et al. [6], this effect prevails over the reduction of the specific heat for large steam concentrations. On the other hand, the enhancement of char gasification by steam increases $\mathrm{CO}$ concentration in the surroundings of the particle, displacing the oxygen, and reduces the temperature due to its endothermicity. The increase of ignition temperature is also observed when steam is further added up to $40 \%$. For the $21 \% \mathrm{O}_{2}$ atmospheres, these increases are of $16 \mathrm{~K}$ for the bituminous and $13 \mathrm{~K}$ for the subbituminous coal, when replacing $\mathrm{CO}_{2}$ by $\mathrm{H}_{2} \mathrm{O}$ from $10 \%$ to $40 \%$.

The effect of the progressive $\mathrm{CO}_{2}$ substitution by $\mathrm{H}_{2} \mathrm{O}$ results in a " $\mathrm{U}$-shape" evolution, firstly decreasing the ignition temperature and later increasing it. As the steam concentration grows, it can be supposed that the increase of radiative heat absorption and the enhancement of char gasification contribute to a delay of the ignition in comparison to the lower $\mathrm{H}_{2} \mathrm{O}$ case, prevailing over the effect caused by a larger $\mathrm{O}_{2}$ diffusivity in the atmosphere.

When oxygen concentration is augmented from $21 \%$ to $35 \%$, the trend is the same but the evolution is flattened with softer temperature variations. The effect of the steam is attenuated under high $\mathrm{O}_{2}$ concentrations, which is consistent with previous experiences $[4,8]$. In comparison to the dry $\mathrm{O}_{2} / \mathrm{CO}_{2}$ atmospheres, a $40 \% \mathrm{CO}_{2}$ replacement by $\mathrm{H}_{2} \mathrm{O}$ barely affects the ignition temperature, with maximum differences of $6 \mathrm{~K}$. 


\subsection{Burnout.}

Figures 3 and 4 show the burnout degrees obtained under the different atmospheres tested, for SA and CB coals respectively. These conversion rates have been calculated according to the Eq. (2) provided in the section 2.2. Replacement of $\mathrm{CO}_{2}$ by $\mathrm{H}_{2} \mathrm{O}$ should yield larger burnout degrees, due to the higher $\mathrm{H}_{2} \mathrm{O}$ reactivity. This is related to the increase of the gas-phase temperature, the higher $\mathrm{O}_{2}$ diffusivity in $\mathrm{H}_{2} \mathrm{O}$ than in $\mathrm{CO}_{2}$, and the enhancement of char gasification when $\mathrm{H}_{2} \mathrm{O}$ concentration is augmented.

Since the tests were defined to keep the same residence time, burnout degrees are consistently higher for the sub-bituminous coal, due to its major reactivity. Indeed, very high conversion rates are obtained for all the conditions during the CB tests -see Figure 4-, with small differences among them. In the case of the SA bituminous coal, supply of $10 \% \mathrm{H}_{2} \mathrm{O}$ as $\mathrm{CO}_{2}$ replacement always increases the burnout degree in comparison to the dry $\mathrm{O}_{2} / \mathrm{CO}_{2}$ situations. For the $21 \% \mathrm{O}_{2}$ atmosphere, a significant increase of nearly 5 percentage points is observed. This steam-induced effect is explained by the increase of both the gas-phase temperature and the $\mathrm{O}_{2}$ diffusivity. The comparative increases also observed for the $30 \% \mathrm{O}_{2}$ and $35 \% \mathrm{O}_{2}$ atmospheres are not so large; the higher conversion rates and oxidant availability attenuate the rising effect caused by the $10 \% \mathrm{H}_{2} \mathrm{O}$ addition. When steam is further added from $10 \%$ to $25 \%$ an additional increase of burnout is obtained, but not proportionally to the steam concentration leap. These differences range within 0.51-1.98 percentage points. Besides the influences on the temperature and the $\mathrm{O}_{2}$ diffusivity, $\mathrm{H}_{2} \mathrm{O}$ also enhances char gasification in comparison to $\mathrm{CO}_{2}$ [21]. This also contributes to a larger solid-to-gas conversion rates when steam concentration is augmented as $\mathrm{CO}_{2}$ replacement.

Contrariwise, a different trend is shown when increasing steam addition from $25 \%$ to $40 \%$. For the $21 \% \mathrm{O}_{2}$ atmosphere the variation is small, but a decrease of burnout degree is detected for the $30 \% \mathrm{O}_{2}$ and $35 \% \mathrm{O}_{2}$ cases: 1.85 and 1.03 percentage points respectively. The only explanation for this behaviour relies on the reduction of the char specific surface caused by the enriched $-\mathrm{H}_{2} \mathrm{O}$ atmosphere in comparison to $\mathrm{CO}_{2}$ [22], which affects the char conversion rates. To support this conclusion, BET surface areas have been determined for residues samples taken from two of the bituminous coal tests: $35 / 65 \% \quad \mathrm{O}_{2} / \mathrm{CO}_{2}$ and $35 / 25 / 40 \% \quad \mathrm{O}_{2} / \mathrm{CO}_{2} / \mathrm{H}_{2} \mathrm{O}$. The used technique is $\mathrm{N}_{2}$ isothermal adsorption at $77 \mathrm{~K}$, determined with a gas sorption analyzer ASAP 2020 (Micromeritics) in a certified laboratory. The samples were previously degassed at $250{ }^{\circ} \mathrm{C}$ during 5 hours. 
261 The BET surface areas obtained are $164.5 \mathrm{~m}^{2} / \mathrm{g}\left(35 / 65 \% \quad \mathrm{O}_{2} / \mathrm{CO}_{2}\right)$ and $107.5 \mathrm{~m}^{2} / \mathrm{g}$ $262\left(35 / 25 / 40 \% \mathrm{O}_{2} / \mathrm{CO}_{2} / \mathrm{H}_{2} \mathrm{O}\right)$, which means a reduction of $34.6 \%$.

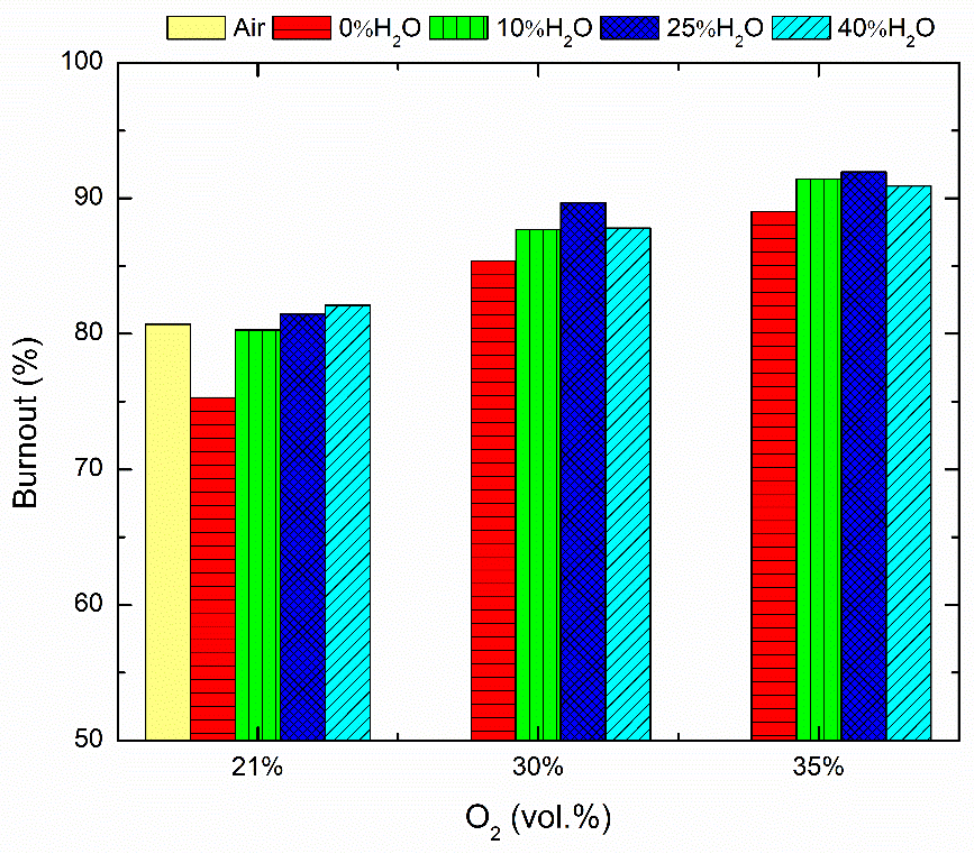

Figure 3.- Burnout degree obtained under air and different $\mathrm{O}_{2} / \mathrm{CO}_{2}$ and $\mathrm{O}_{2} / \mathrm{H}_{2} \mathrm{O} / \mathrm{CO}_{2}$ atmospheres (steam is added as $\mathrm{CO}_{2}$ replacement), for the $\mathrm{SA}$ bituminous coal.

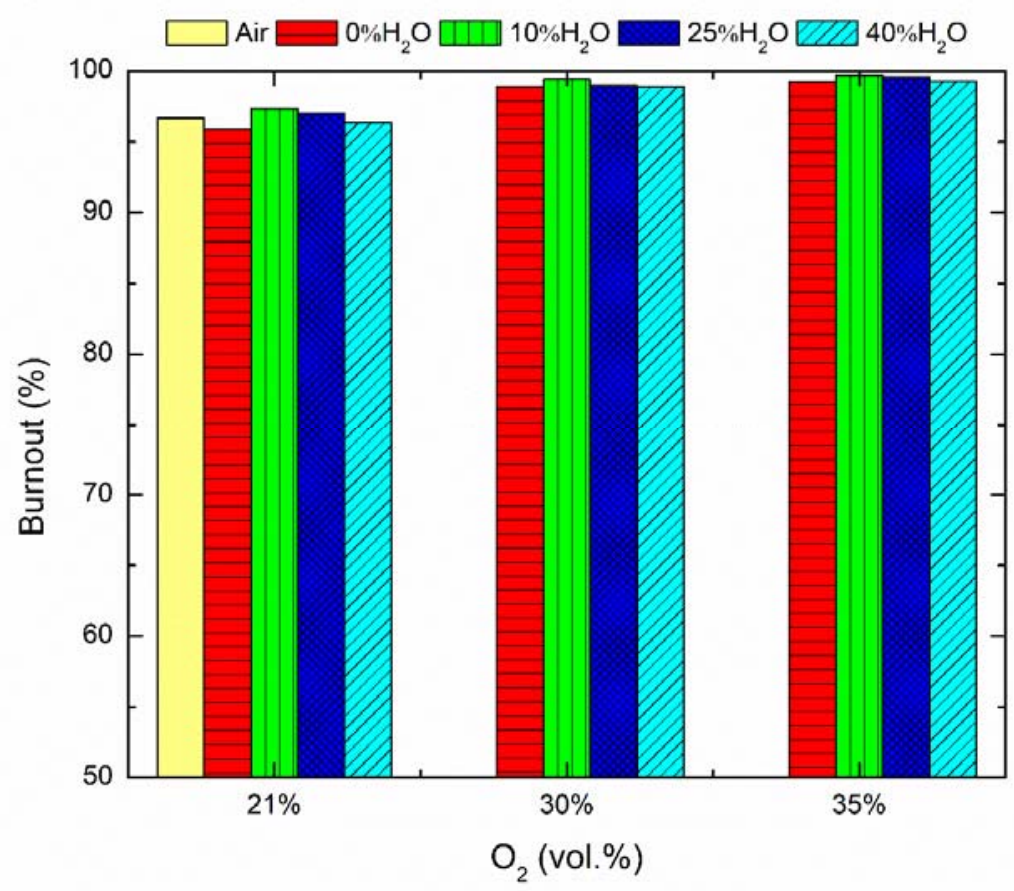

Figure 4.- Burnout degree obtained under air and different $\mathrm{O}_{2} / \mathrm{CO}_{2}$ and $\mathrm{O}_{2} / \mathrm{H}_{2} \mathrm{O} / \mathrm{CO}_{2}$ atmospheres 
The effect of steam on the burnout degree for the CB sub-bituminous coal is partially hindered by the high conversion rates achieved under all the atmospheres, as shown in

271 Figure 4. Anyway, although in a much lower extent, the trend is similar to the discussed 272 for the high-rank coal. Replacement of $10 \% \mathrm{CO}_{2}$ by $\mathrm{H}_{2} \mathrm{O}$ yields an increase of burnout 273 degree for all the three $\mathrm{O}_{2}$ concentrations ( $0.45-1.45$ percentage points), the maximum 274 values are not obtained for the $40 \% \mathrm{H}_{2} \mathrm{O}$ cases, and the effect of steam on burnout is 275 attenuated when atmospheres are enriched in $\mathrm{O}_{2}$.

The slight burnout decrease observed when increasing steam concentration from $10 \%$ to $25 \%$ and to $40 \%$ is again explained by the decrease of the char specific surface. 278 According to Feng et al. [23], the lower the rank of the coal, the more the pore 279 development inside the char structure due to a quick precipitation of volatile matter. 280 Pallarés et al. [24] reported a maximum reduction of 43\% in BET specific surfaces for a 281 high volatile fuel, when replacing $\mathrm{CO}_{2}$ by $\mathrm{H}_{2} \mathrm{O}$ for activation. These experiences are 282 consistent with the observations in Figures 3 and 4: the maximum burnout degree was 283 detected for the $35 / 10 \% \mathrm{O}_{2} / \mathrm{H}_{2} \mathrm{O}$ case when firing the $\mathrm{CB}$ sub-bituminous coal, but it was 284 for the $35 / 25 \% \mathrm{O}_{2} / \mathrm{H}_{2} \mathrm{O}$ case when firing the $\mathrm{SA}$ bituminous one. Notwithstanding, the 285 high reactivity of the sub-bituminous coal brings burnout to be very little sensitive to the 286 firing atmosphere.

The burnout degrees under conventional air combustion are also included in Figures 3 and 4: $80.7 \%$ for the SA coal and $96.7 \%$ for the $\mathrm{CB}$ one. The shift from $\mathrm{O}_{2} / \mathrm{N}_{2}$ to $\mathrm{O}_{2} / \mathrm{CO}_{2}$ combustion involves a burnout decrease, due to the reduction of the gas temperature caused by the higher specific heat of $\mathrm{CO}_{2}$ compared to $\mathrm{N}_{2}$, and the lower diffusivity of $\mathrm{O}_{2}$ in $\mathrm{CO}_{2}$ than in $\mathrm{N}_{2}$. As explained in the previous paragraphs, steam addition as $\mathrm{CO}_{2}$

292 replacement produces the opposite effect, thereby resulting in similar or higher burnout 293 values than the obtained under air combustion.

\section{3. $\mathrm{CO}$ in flue gases.}

295 Burnout degree accounts for the solid-to-gas conversion, but it does not provide 296 information about the evolution to final products in the gas-phase. This can be indicated 297 by the presence of carbon monoxide in the flue gases leaving the reactor. CO specific 298 concentrations in flue gases are shown in Tables 6 and 7, for the SA and CB coals 299 respectively. It is clearly seen in these tables that CO levels are significantly lowered 300 when the atmosphere is $\mathrm{O}_{2}$-enriched. Indeed, the concentrations are below the detection 301 limit for some of the experiments with the CB sub-bituminous coal. 


\begin{tabular}{rcccc} 
& Air & $21 \% \mathrm{O}_{2}$ & $30 \% \mathrm{O}_{2}$ & $35 \% \mathrm{O}_{2}$ \\
\hline $0 \% \mathrm{H}_{2} \mathrm{O}$ & 5.7 & 7.1 & 3.2 & 2.3 \\
$25 \% \mathrm{H}_{2} \mathrm{O}$ & - & 6.6 & 2.2 & 1.2 \\
$40 \% \mathrm{H}_{2} \mathrm{O}$ & - & 16.0 & 2.8 & 2.1 \\
\hline
\end{tabular}

302

303

304

305

306

Table 6.- $\mathrm{CO}$ specific emissions ( $\mathrm{mg} / \mathrm{g}_{\text {coal }}$ ) obtained under air and different $\mathrm{O}_{2} / \mathrm{CO}_{2}$ and $\mathrm{O}_{2} / \mathrm{H}_{2} \mathrm{O} / \mathrm{CO}_{2}$ atmospheres (steam is added as $\mathrm{CO}_{2}$ replacement), for the SA bituminous coal.

\begin{tabular}{rcccc} 
& Air & $21 \% \mathrm{O}_{2}$ & $30 \% \mathrm{O}_{2}$ & $35 \% \mathrm{O}_{2}$ \\
\hline $0 \% \mathrm{H}_{2} \mathrm{O}$ & 2.7 & 9.6 & 1.1 & 0.2 \\
$25 \% \mathrm{H}_{2} \mathrm{O}$ & - & 6.0 & 0.2 & 0.0 \\
$40 \% \mathrm{H}_{2} \mathrm{O}$ & - & 7.7 & 2.9 & 0.2 \\
\hline
\end{tabular}

Table 7.- $\mathrm{CO}$ specific emissions (mg/g $\mathrm{g}_{\text {coal }}$ ) obtained under air and different $\mathrm{O}_{2} / \mathrm{CO}_{2}$ and $\mathrm{O}_{2} / \mathrm{H}_{2} \mathrm{O} / \mathrm{CO}_{2}$ atmospheres (steam is added as $\mathrm{CO}_{2}$ replacement), for the $\mathrm{CB}$ sub-bituminous coal.

The $\mathrm{CO}_{2}$ replacement by $\mathrm{H}_{2} \mathrm{O}$ can affect to $\mathrm{CO}$ detected at reactor outlet by several, overlapped pathways. On the one hand, steam enhances char gasification in comparison to $\mathrm{CO}_{2}$ but, on the other hand, $\mathrm{O}_{2}$ diffusivity is higher in $\mathrm{H}_{2} \mathrm{O}$ than in $\mathrm{CO}_{2}$. Whilst the former promotes $\mathrm{CO}$ release, the latter enhances $\mathrm{CO}$ oxidation to $\mathrm{CO}_{2}$. Besides, steam gasification effects are weakened for high $\mathrm{O}_{2}$ concentrations, according to Hecht et al. [22]. In addition, as discussed in the following section, $\mathrm{H}_{2} \mathrm{O}$ also plays a role in the NO formation/depletion mechanisms, and NO can interact with $\mathrm{CO}$ evolving towards $\mathrm{CO}_{2}$ and $\mathrm{N}_{2}$.

The results shown in Tables 6 and 7 point to a decrease in CO concentrations when $\mathrm{CO}_{2}$ is replaced in a rate of $25 \% \mathrm{H}_{2} \mathrm{O}$ : all they are lower than the measured under the dry $\mathrm{O}_{2} / \mathrm{CO}_{2}$ atmospheres. But the trend is reversed for the $40 \% \mathrm{H}_{2} \mathrm{O}$ addition, even surpassing in some cases the levels corresponding to the dry atmospheres. The effect is more relevant for the high-rank coal and the poorer $\mathrm{O}_{2}$ atmosphere (21\%). According to these observations, large steam addition significantly enhances char gasification promoting $\mathrm{CO}$ release, which cannot be totally compensated by the increase of oxidant diffusivity along the reactor height. Anyway, all the values are very low (below $3.2 \mathrm{mg} \mathrm{CO} / \mathrm{g}$ coal) for the $30 \%$ and $35 \% \mathrm{O}_{2}$ atmospheres, independently of the coal rank or the steam concentration.

Aiming at relating the operating conditions with the carbon behaviour, an index has 
(i.e. a comparison of the carbon conversion with the fuel averaged conversion). This index

328 has been obtained from the carbon content in the coal and the $\mathrm{CO}$ and $\mathrm{CO}_{2}$ 329 concentrations in flue gases. The results have been comprised in the range $0.95-0.98$ for 330 the bituminous coal and 0.98-0.99 for the sub-bituminous coal. Differences are very 331 small, and cannot be related to the specifics of every test.

\subsection{NO formation.}

The extent of $\mathrm{NO}_{\mathrm{x}}$ formation and reduction under $\mathrm{O}_{2} / \mathrm{CO}_{2}$ combustion has already been experimentally characterized for a wide range of fuels and conditions [13, 25-28], but large steam concentrations under oxy-steam combustion can result in very different insights. Steam participates in both homogeneous reactions (involving N-volatiles) and heterogeneous ones (involving $\mathrm{N}$-char), then the fuel rank is also a question that must be accounted.

$\mathrm{CO}_{2}$ replacement by $\mathrm{H}_{2} \mathrm{O}$ leads to an increase of gas temperature and $\mathrm{O}_{2}$ diffusivity, as commented in previous sections, which increases the oxidation rates of $\mathrm{N}$-fuel to NO. On the contrary, steam can contribute to reduce or inhibit NO formation by different ways. In the gas-phase, steam interacts with $\mathrm{HCN}$ over $600{ }^{\circ} \mathrm{C}$ according to the reaction R.1 [16, 29, 30], competing with $\mathrm{HCN}$ oxidation and releasing $\mathrm{NH}_{3}$ that can further reduce NO (R.2). Besides, large steam concentration promotes the presence of an $\mathrm{OH}+\mathrm{H}$ radical pool in the flame, also competing with $\mathrm{HCN}$ oxidation through the reactions R.3 and R.4 [26].

$$
\mathrm{HCN}+\mathrm{OH} \leftrightarrow \mathrm{H}_{2} \mathrm{O}+\mathrm{CN}
$$

In comparison to $\mathrm{CO}_{2}$, steam intensifies char gasification releasing $\mathrm{CO}$ that can contribute to reduce NO by the homogeneous reaction (R.5), catalysed by the char surface [31]. This reducing effect can be attenuated by the presence of $\mathrm{OH}$ radicals, since they contribute to $\mathrm{CO}$ depletion by means of the reaction (R.6). These opposite trends were suggested by Zhijun et al. [18] to explain $\mathrm{H}_{2} \mathrm{O} / \mathrm{CO}_{2}$ ratios minimizing $\mathrm{NO}$ formation rates. 
Enhancement of char gasification by steam increases carbon-free sites on the char surface, which can reduce NO by the heterogeneous reaction R.7 [31]. Competitively, char also reacts with $\mathrm{H}$ radicals releasing $\mathrm{HCN}$ according to reaction R.8 [32]. The fate of $\mathrm{HCN}$ in the gas-phase will produce either $\mathrm{NO}$ by oxidation or $\mathrm{N}_{2}$ by reduction mechanisms.

$$
\begin{gathered}
\mathrm{C}_{\mathrm{s}}+\mathrm{NO} \rightarrow \frac{1}{2} \mathrm{~N}_{2}+\mathrm{CO} \\
\mathrm{C}(\mathrm{N})_{\mathrm{s}}+\mathrm{H} \rightarrow \mathrm{HCN}
\end{gathered}
$$

In order to ascertain the role of steam addition on the NO formation for the two coals selected in this work, fuel-N to NO mass conversion rates were calculated for all the $\mathrm{O}_{2} / \mathrm{CO}_{2} / \mathrm{H}_{2} \mathrm{O}$ tests previously presented in Tables 4 and 5: three oxygen concentrations (21, 30 and $35 \%)$, varying steam fraction in the range $0-40 \%$ and oxygen excess $\lambda=1.25$. The mean results and standard deviations are depicted in Figures 5 and 6 , for SA and CB coals respectively. The maximum standard deviations of the recorded NO measurements during the steady-state operation were comprised in the range $0.5-3.5 \%$ of the mean values.

As concerns the $\mathrm{CB}$ sub-bituminous coal, see Figure 6, the effect of the $\mathrm{CO}_{2}$ replacement by $\mathrm{H}_{2} \mathrm{O}$ is small if compared to the SA bituminous coal (Figure 5). For low rank solid fuels, $\mathrm{HCN}$ release is attenuated in comparison to $\mathrm{NH}_{3}$ one, especially under wet conditions [33]. Then, the extent of the $\mathrm{HCN}-\mathrm{H}_{2} \mathrm{O}$ mechanisms is more limited. No detailed measurements are available in the reactor to discern the role of $\mathrm{HCN}$ and $\mathrm{NH}_{3}$, but the lower variations of the conversions for the $\mathrm{CB}$ coal tests are consistent with that limited extent. These limited reductions in the conversion levels are observed in Figure 6 when $10 \% \mathrm{H}_{2} \mathrm{O}$ is added, with a maximum decrease of $3.5 \%$ for the $21 \% \mathrm{O}_{2}$ case. This is reversed in the $40 \% \mathrm{H}_{2} \mathrm{O}$ tests, even overpassing the conversion rates obtained for the dry $\mathrm{O}_{2} / \mathrm{CO}_{2}$ atmospheres. Moreover, the effect of steam is smoothed as the atmosphere is enriched in $\mathrm{O}_{2}$. The trend observed in Figure 6, where an optimum $\mathrm{H}_{2} \mathrm{O}$ value is leading to the lower fuel-N to NO conversion rate, may be explained by the opposite, overlapped mechanisms in the gas-phase. Initially, for low steam rates, the reductions given by the 


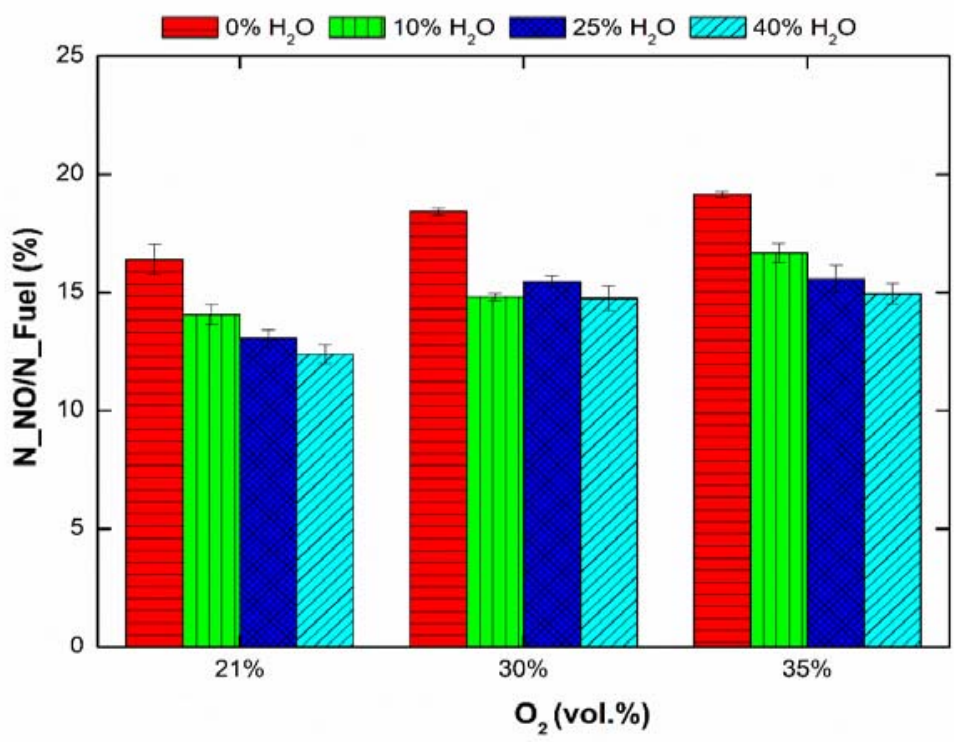

Figure 5.- Fuel-N to NO conversions obtained under different $\mathrm{O}_{2} / \mathrm{CO}_{2}$ and $\mathrm{O}_{2} / \mathrm{H}_{2} \mathrm{O} / \mathrm{CO}_{2}$ atmospheres

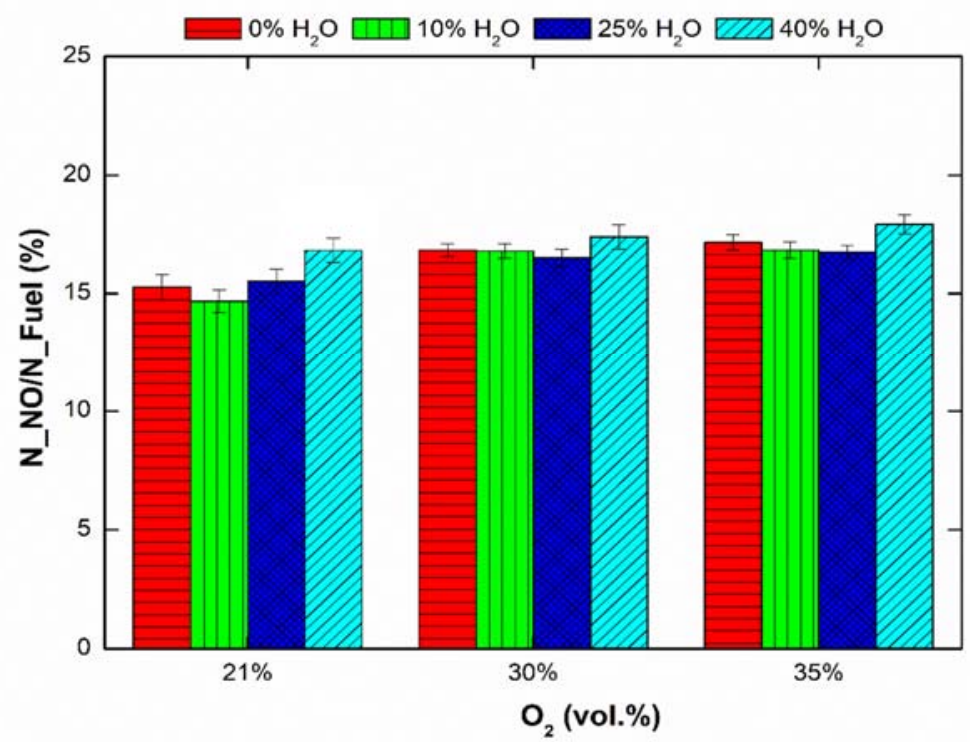

Figure 6.- Fuel- $\mathrm{N}$ to $\mathrm{NO}$ conversions obtained under different $\mathrm{O}_{2} / \mathrm{CO}_{2}$ and $\mathrm{O}_{2} / \mathrm{H}_{2} \mathrm{O} / \mathrm{CO}_{2}$ atmospheres 
The results in Figure 5, related to the SA bituminous coal, follow a very different trend to those shown in Figure 6, what points to the effect of the coal rank. Significant 398 decreases in the conversion rates to $\mathrm{NO}$ are obtained, for all the $\mathrm{O}_{2}$ levels, when $10 \%$ $399 \mathrm{H}_{2} \mathrm{O}$ replaces $\mathrm{CO}_{2}$. Further decrements are obtained when $40 \% \mathrm{H}_{2} \mathrm{O}$ is added to the 400 atmospheres, however not proportional to the increase of the steam percentage. This 401 behaviour is related to the composition of the SA coal, whose fixed carbon/volatiles ratio 402 is 1.9 times higher than the sub-bituminous one (in dry and ash free basis). The observed 403 reduction in the conversions to NO may be mostly related to the intensified gasification 404 caused by $\mathrm{H}_{2} \mathrm{O}$. Heterogeneous reaction R.7 with fixed carbon and homogeneous reaction 405 R.5 with $\mathrm{CO}$ (catalysed by char) are influential mechanisms. $\mathrm{HCN}-\mathrm{H}_{2} \mathrm{O}$ interaction also 406 contribute to the reduction, as well as other intermediate species (CN, NCO, HNCO) 407 reacting with radicals $\mathrm{H}$ and $\mathrm{OH}$ [26]. The increase in steam concentrations from $10 \%$ to $40840 \%$, thus rising $\mathrm{O}_{2}$ diffusivity, does not overturn the decreasing trend for conversion to 409 NO and just attenuates it.

To better see the different effects observed between the fired coals, Figure 7 compares 411 the accumulative variation (\%) of fuel- $\mathrm{N}$ to $\mathrm{NO}$ mass conversion rates when $\mathrm{H}_{2} \mathrm{O}$ is replacing $\mathrm{CO}_{2}$ in the atmosphere. A third coal is also included for comparison purposes: high-rank anthracite, which was tested in the same facility and under the same conditions. Details about those tests and specific results can be found in reference [8]. As seen in the Figure 7, the higher the coal rank, the larger the influence of steam in reducing NO formation rates: maximum reductions of $45 \%$ in the case of the anthracite, and $24 \%$ in the case of the SA bituminous coal. For the CB sub-bituminous coal, the reduction is very limited and only detected for the lower steam concentrations, and an increase of $2-9 \%$ in $\mathrm{NO}$ is obtained for the $40 \% \mathrm{H}_{2} \mathrm{O}$ tests.

High rank coals would demand an increase of oxygen excesses to complete conversion, and it is well-known that this would lead to an increase on NO formation rates from the nitrogen bound in the fuel. For this reason, additional tests were carried out increasing oxygen excess (over stoichiometry) from $\lambda=1.25$ to $\lambda=1.35$ and $\lambda=1.45$-flow rates defined to keep constant the residence time in the reactor, same as explained in section 2.3.2-. Figure 8 summarizes the results obtained, showing the accumulative variation (\%) of fuel- $\mathrm{N}$ to $\mathrm{NO}$ conversion rates as a function of the oxygen excess. The extent of the increases found for anthracite and bituminous coal is, in all cases, lower that the decreases respectively found for the $40 \% \mathrm{H}_{2} \mathrm{O}$ atmospheres in Figure 7. 


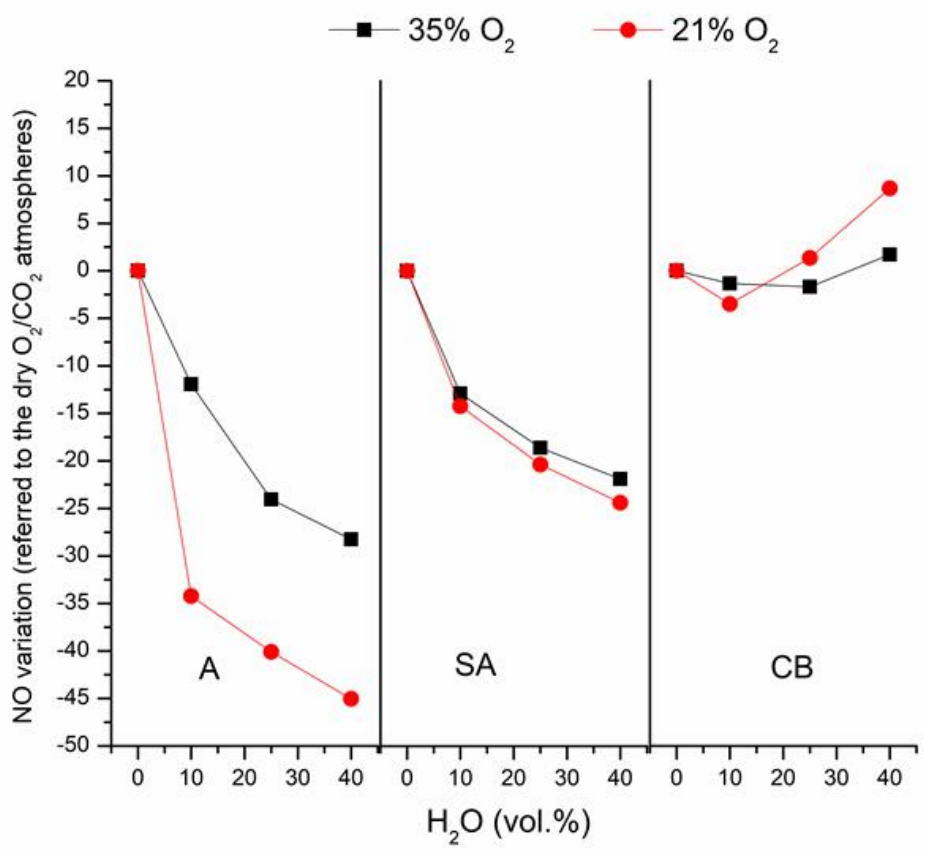

Figure 7.- Comparison of the accumulative variation (\%) in fuel-N to NO mass conversion for different $\mathrm{H}_{2} \mathrm{O}$ percentages, for anthracite (A), bituminous coal (SA) and sub-bituminous coal (CB). Anthracite results can

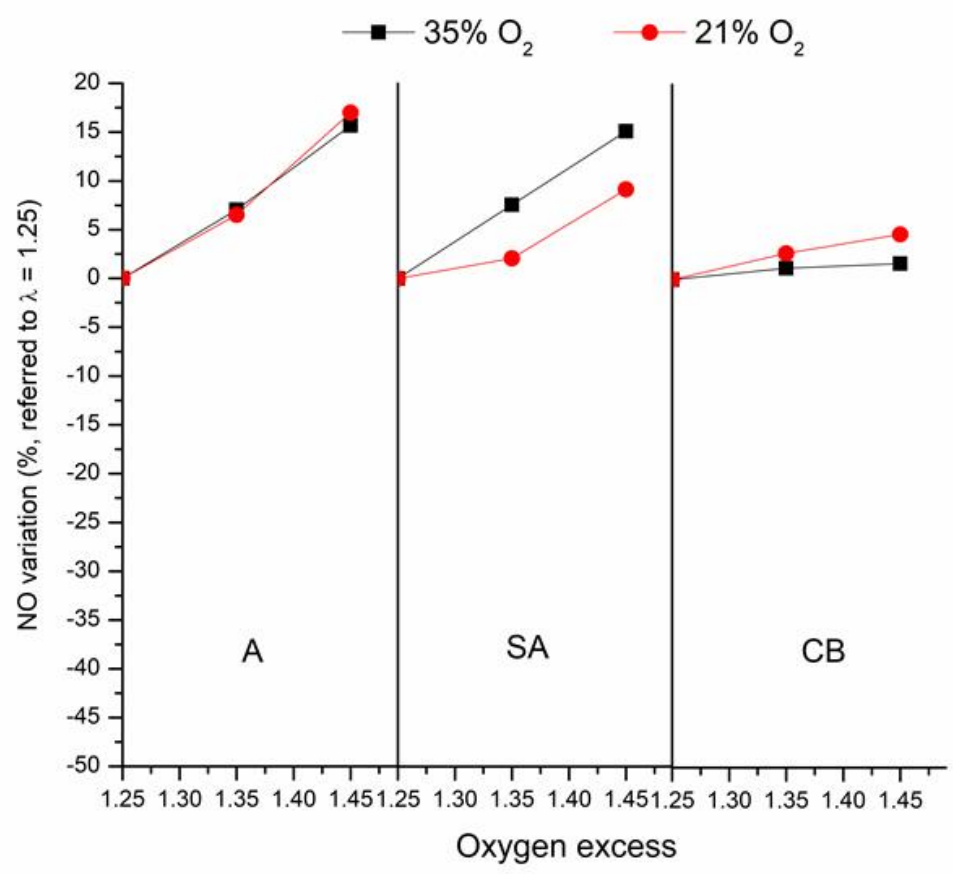

Figure 8.- Comparison of the accumulative variation (\%) in fuel-N to NO mass conversion for different can be consulted in Ref. [8]. 
To conclude, it is worth mentioning that $\mathrm{CO}_{2}$ replacement by $\mathrm{H}_{2} \mathrm{O}$ is leading to a 440 twofold benefit for the SA bituminous coal, in comparison to the dry situations: an 441 increase of burnout degrees along with a decrease of fuel-N to NO mass conversion rates, 442 for every $\mathrm{O}_{2}$ concentration. This joint outcome is represented in Figure 9, merging the 443 results previously shown in Figures 3 and 5. A similar representation is given in Figure 44410 for the $\mathrm{CB}$ sub-bituminous coal: in this case, the $\mathrm{CO}_{2}$ replacement by $\mathrm{H}_{2} \mathrm{O}$ increases 445 the $\mathrm{NO}$ formation rates for the $40 \% \mathrm{H}_{2} \mathrm{O}$ atmospheres in comparison to the dry ones.

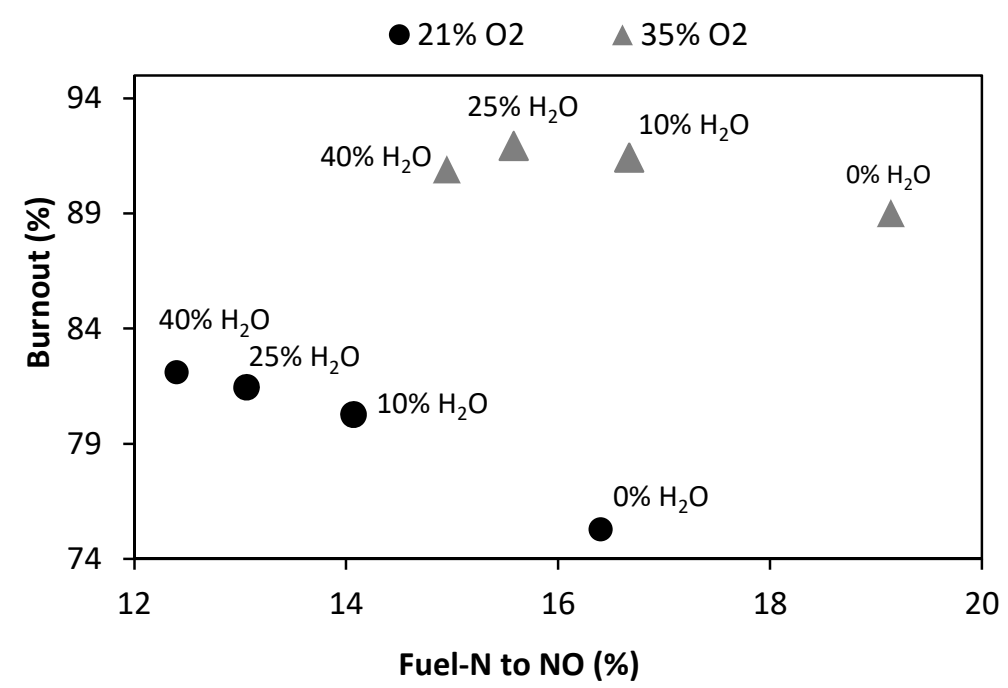

446

Figure 9.- Fuel-N to NO conversions vs. burnout degrees, for the SA bituminous coal.

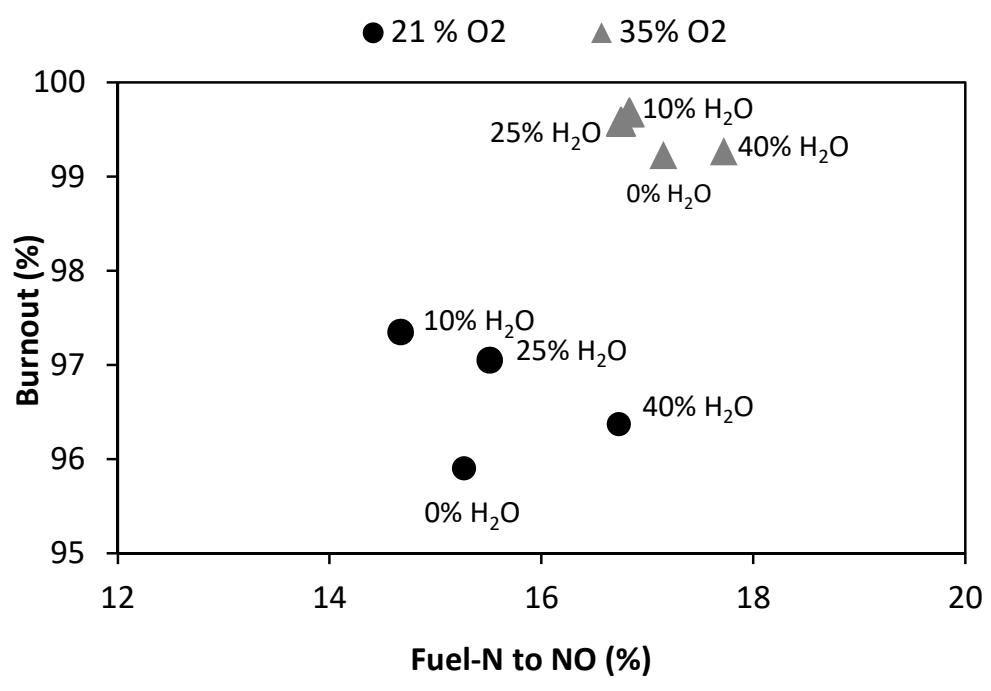




\section{Conclusions}

452

453

454

455

456

457

458

459

460

461

462

463

464

465

466

467

468

469

470

471

472

473

474

475

476

477

478

479

480

481

482

483

The combustion characteristics of two different coals have been experimentally determined in an entrained flow reactor, for a set of $\mathrm{O}_{2} / \mathrm{N}_{2}, \mathrm{O}_{2} / \mathrm{CO}_{2}$ and $\mathrm{O}_{2} / \mathrm{H}_{2} \mathrm{O} / \mathrm{CO}_{2}$ atmospheres. Besides the influence of the coal rank, the effect of replacing $\mathrm{CO}_{2}$ by $\mathrm{H}_{2} \mathrm{O}$ on the ignition, burnout and NO formation has been sought. Steam concentration was increased up to $40 \%$, while oxygen concentration up to $35 \%$. The following outcomes have been obtained:

- Regardless the coal type and $\mathrm{O}_{2}$ concentration, it is observed that: 1) addition of steam in low rates (10\%) decreases ignition temperature, 2) the trend is reversed when steam concentration is further incremented to $25 \%$ and $40 \%$. The differences in ignition temperatures are minimally higher for the subbituminous coal. Replacement of $40 \% \mathrm{CO}_{2}$ by $\mathrm{H}_{2} \mathrm{O}$ yields a small variation of the ignition temperature in comparison to the dry atmospheres.

- The burnout degree of the bituminous coal is increased when $\mathrm{CO}_{2}$ is replaced by $\mathrm{H}_{2} \mathrm{O}$ in the firing atmosphere, but the largest conversions are not detected for the maximum steam concentrations. The extent of the steam influence on the burnout degree is attenuated when the atmosphere is enriched in $\mathrm{O}_{2}$. As concerns the sub-bituminous coal, its reactivity produces very high conversion rates for all the atmospheres tested and the effect of $\mathrm{CO}_{2}$ replacement by $\mathrm{H}_{2} \mathrm{O}$ is similar but much more narrowed.

- The influence of steam on NO formation is very different depending on the coal rank. A significant decrease in fuel-N to NO conversion rate is observed for the bituminous coal when replacing $40 \% \mathrm{CO}_{2}$, but an increase is observed for the sub-bituminous one. Their different volatiles/char ratio determines the extent of homogeneous and heterogeneous mechanisms in which steam is involved. The effect of oxygen excess on NO formation has been proved to be less influential than the effect of the steam concentration.

\section{Acknowledgements}

The work described in this paper has been funded by the R+D Spanish National Program from the Spanish Ministry of Science, Innovation and Universities, under the Projects ENE2015-67448 and RTI2018-094488, and the Grant BES-2016-078573. 
Dr. M.C. Mayoral, Dr. J.M. Andrés and Dr. J. Pallarés are gratefully acknowledged for providing the samples of the coals. The Service of Electronic Instrumentation (University of Zaragoza) is also acknowledged for their support in the development of the SCADA at the experimental facility.

\section{References}

[1] International Energy Agency, https://www.iea.org/fuels-and-technologies/coal, 2020 [14/05/2020].

[2] C. Salvador, Modeling, design and pilot-scale experiments of CANMET's advanced oxy-fuel/steam burner, $2^{\text {nd }}$ Workshop International Oxy-Combustion Research Network, Windsor, CT, USA, 2007.

[3] S. Seepana, S. Jayanti, Steam-moderated oxy-fuel combustion, Energy Convers Management 51 (2010) 1981-1988.

[4] W. Prationo, L. Zhang, Influence of steam on ignition of Victorian brown coal particle stream in oxy-fuel combustion: In-situ diagnosis and transient ignition modelling, Fuel 181 (2016) 1203-1213.

[5] R.B. Kops, F.M. Pereira, M. Rabaçal, M. Costa, Effect of steam on the single particle ignition of solid fuels in a drop tube furnace under air and simulated oxyfuel conditions, Proceedings of the Combustion Institute 37 (2019) 2977-2985.

[6] J. Riaza, L. Álvarez, M.V. Gil., C. Pevida, J.J. Pis, F. Rubiera. Effect of oxy-fuel combustion with steam addition on coal ignition and burnout in an entrained flow reactor, Energy 36 (2011) 5314-5319.

[7] L. Cai, C. Zou, Y. Guan, H. Jia, L. Zhang, C. Zheng, Effect of steam on ignition of pulverized coal particles in oxy-fuel combustion in a drop tube furnace, Fuel 182 (2016) 958-966.

[8] A.I. Escudero, M. Aznar, L. I. Díez, M. C. Mayoral, J. M. Andrés, From $\mathrm{O}_{2} / \mathrm{CO}_{2}$ to $\mathrm{O}_{2} / \mathrm{H}_{2} \mathrm{O}$ combustion: The effect of large steam addition on anthracite ignition, burnout and $\mathrm{NO}_{\mathrm{x}}$ formation, Fuel Processing Technology 206 (2020) 106432.

[9] C. Zou, L. Cai, D. Wu, Y. Liu, S. Liu, C. Zheng, Ignition behaviors of pulverized coal particles in $\mathrm{O}_{2} / \mathrm{N}_{2}$ and $\mathrm{O}_{2} / \mathrm{H}_{2} \mathrm{O}$ mixtures in a drop tube furnace using flame monitoring techniques, Proceedings of Combustion Institute 35 (2015) 3629-3636.

[10] Z. Hao, Y. Li, N. Li, K. Cen, Experimental investigation of ignition and combustion characteristics of single coal and biomass particles in $\mathrm{O}_{2} / \mathrm{N}_{2}$ and $\mathrm{O}_{2} / \mathrm{H}_{2} \mathrm{O}$, Journal of the Energy Institute 92 (2019) 502-511. 
[11] L. Álvarez, M. Gharebaghi, M. Pourkashanian, A. Williams, J. Riaza, C. Pevida, J.J. Pis, F. Rubiera, CFD modelling of oxy-coal combustion in an entrained flow reactor, Fuel Processing Technology 92 (2011) 1489-1497.

[12] X. Jiang, X. Huang, J. Liu, X. Han, $\mathrm{NO}_{\mathrm{x}}$ emission of fine and superfine pulverized coal combustion in $\mathrm{O}_{2} / \mathrm{CO}_{2}$ atmosphere, Energy and Fuels 24 (2010) 6307-6313.

[13] H. Hashemi, S. Hansen, M.B. Toftegaard, K.H. Pedersen, A.D. Jensen, K. DamJohansen, et al., A model for nitrogen chemistry in oxy-fuel combustion of pulverized coal, Energy and Fuels 25 (2011) 4280-4289.

[14] H. Liu, R. Zailani, B.M. Gibbs, Comparisons of pulverized coal combustion in air and in mixtures of $\mathrm{O}_{2} / \mathrm{CO}_{2}$, Fuel 84 (2005) 833-840.

[15] W. Moron, W. Rybak, $\mathrm{NO}_{\mathrm{x}}$ and $\mathrm{SO}_{2}$ emissions of coals, biomass and their blends under different oxy-fuel atmospheres, Atmospheric Environment 116 (2015) 65-71.

[16] L. Álvarez, J. Riaza, M.V. Gil, C. Pevida, J.J. Pis, F. Rubiera, NO emissions in oxycoal combustion with the addition of steam in an entrained flow reactor, Greenhouse Gases Science Technology 1 (2011) 180-190.

[17] L. Yupeng, S. Rui, W. Jiangquan, W. Zhuozhi, W. Min, Song Zhenyu, Effect of $\mathrm{H}_{2} \mathrm{O}$ on char-nitrogen conversion during char- $\mathrm{O}_{2} / \mathrm{H}_{2} \mathrm{O}$ combustion under hightemperature entrained flow conditions, Combustion and Flame 207 (2019) 391405.

[18] S. Zhijun, S. Su, J. Xu, K. Xu, S. Hu, Y. Wang, L. Jiang, N. Si, Y. Zhou, S. S. A. Syed-Hassan, A. Zhang, J. Xiang, Effects of $\mathrm{H}_{2} \mathrm{O}$ on NO emission during oxy-coal combustion with wet recycle, Energy and Fuels 31 (2017) 8392-8399.

[19] J. Faúndez, B. Arias, F. Rubiera, A. Arenillas, X. García, A.L. Gordon, J.J. Pis, Ignition characteristics of coal blends in an entrained flow furnace, Fuel 86 (2007) 2076-2080.

[20] J. Riaza, J. Gibbins, H. Chalmers, Ignition and combustion of single particles of coal and biomass, Fuel 202 (2017) 650-655.

[21] E. S. Hecht, C. R. Shaddix, M. Geier, A. Molina, B. S. Haynes, Effect of $\mathrm{CO}_{2}$ and steam gasification reactions on the oxy-combustion of pulverized coal char, Combustion and Flame 159 (2012) 3437-3447.

[22] J. Xu, S. Su, Z. Sun, N. Si, M. Qing, L. Liu, S. Hu, Y. Wang, J. Xiang, Effects of $\mathrm{H}_{2} \mathrm{O}$ gasification reaction on the characteristics of chars under oxy-fuel combustion conditions with wet recycle, Energy and Fuels 30 (2016) 9071-9079.

[23] D. Feng, D. Guo, Y. Zhao, H. Tan, G. Chang, T. Zhang, S. Sun, Formation and $\mathrm{O}_{2} / \mathrm{CO}_{2}$ combustion characteristics of real-environment coal char in hightemperature oxy-fuel conditions, Journal of the Energy Institute 92 (2019) 16701682 . 
[24] J. Pallarés, A. González-Cencerrado, I. Arauzo, Production and characterization of activated carbon from barley straw by physical activation with carbon dioxide and steam, Biomass and Bioenergy 115 (2018) 64-73.

[25] P. Glarborg, A.D. Jensen, J.E. Johnsson, Fuel nitrogen conversion in solid fuel fired systems, Progress in Energy and Combustion Science 29 (2003) 89-113.

[26] P. Glarborg, J. A. Miller, B. Ruscic, S. J. Klippenstein, Modeling nitrogen chemistry in combustion, Progress in Energy and Combustion Science 67 (2018) $31-68$.

[27] L. Chen, S. Z. Yong, A. F. Ghoniem, Oxy-fuel combustion of pulverized coal: Characterization, fundamentals, stabilization and CFD modelling, Progress in Energy and Combustion Science 38 (2012) 156-214.

[28] T. Aihara, K. Matsuoka, T. Kyotani, A. Tomita, Mechanism of $\mathrm{N}_{2}$ formation during coal char oxidation, Proceedings of the Combustion Institute 28 (2000) 2189-2195.

[29] S. Schafer, B. Bonn, Hydrolysis of HCN as an important step in nitrogen oxide formation in fluidised combustion, Part 1: homogeneous reactions, Fuel 79 (2000) 1239-1246.

[30] C. Ndibe, R. Spörl, J. Maier, G. Scheffknecht, Experimental study of $\mathrm{NO}$ and $\mathrm{NO}_{2}$ formation in a PF oxy-fuel firing system, Fuel 107 (2013) 749-756.

[31] I. Aarna,, E.M. Suuberg, A review of the kinetics of the nitric oxide-carbon reaction, Fuel 76 (1997) 475-491.

[32] A. Arenillas, F. Rubiera, J.J. Pis, Nitric oxide reduction in coal combustion: Role of char surface complexes in heterogeneous reactions, Environmental Science \& Technology 36 (2020) 5498-5503.

[33] F-J. Tian, H. Wu, J. Yu, L. J. McKenzie, S. Konstantinidis, J. Hayashi, T. Chiba, C-Z. Li, Formation of $\mathrm{NO}_{\mathrm{x}}$ precursors during the pyrolysis of coal and biomass, Part VIII: effects of pressure on the formation of $\mathrm{NH}_{3}$ and $\mathrm{HCN}$ during the pyrolysis and gasification of Victorian brown coal in steam, Fuel 84 (2005) 2102-2108. 